Article

\title{
Thermal Evolution of Natural Layered Double Hydroxides: Insight from Quintinite, Hydrotalcite, Stichtite, and Iowaite as Reference Samples for $\mathrm{CO}_{3}-$ and Cl-Members of the Hydrotalcite Supergroup
}

\author{
Elena S. Zhitova ${ }^{1,2, *}{ }^{\circ}$, H. Chris Greenwell ${ }^{3}{ }^{(0)}$, Mariya G. Krzhizhanovskaya ${ }^{2}$, \\ David C. Apperley ${ }^{4}{ }^{(}$, Igor V. Pekov ${ }^{5}$ and Victor N. Yakovenchuk ${ }^{6}$ \\ 1 Institute of Volcanology and Seismology, Russian Academy of Sciences, Bulvar Piypa 9, \\ 683006 Petropavlovsk-Kamchatsky, Russia \\ 2 Department of Crystallography, St. Petersburg State University, Universitetskaya nab. 7/9, \\ 199034 St. Petersburg, Russia; mariya.krzhizhanovskaya@spbu.ru \\ 3 Department of Earth Sciences, Durham University, Durham DH1 3LE, UK; chris.greenwell@durham.ac.uk \\ 4 Department of Chemistry, Durham University, Durham DH1 3LE, UK; d.c.apperley@durham.ac.uk \\ 5 Faculty of Geology, Moscow State University, Vorobievy Gory, 119991 Moscow, Russia; igorpekov@mail.ru \\ 6 Kola Science Centre, Russian Academy of Sciences, Fersman Street 14, 184209 Apatity, Russia; \\ yakovenchuk@geoksc.apatity.ru \\ * Correspondence: zhitova_es@mail.ru
}

Received: 28 September 2020; Accepted: 27 October 2020; Published: 28 October 2020

\begin{abstract}
In situ high-temperature powder X-ray diffraction experiments were undertaken for the coarse crystalline natural layered double hydroxides (LDHs) quintinite, hydrotalcite, stichtite, and iowaite in the temperature range $25-1000{ }^{\circ} \mathrm{C}$, with thermal analyses of these minerals and their annealed forms carried out in parallel. In the temperature range from $25^{\circ} \mathrm{C}$ to $170-210^{\circ} \mathrm{C}$ quintinite, hydrotalcite, and stichtite (carbonate members of the LDH family) demonstrated contraction of the basal $d_{00 n}$-value of $0.1-0.3 \AA$, followed by a sharp contraction of $1.0-1.1 \AA$ at $T>170-210{ }^{\circ} \mathrm{C}$. The high-temperature modified states were stable up to $380-420^{\circ} \mathrm{C}$, before decomposing to an amorphous phase. Iowaite (chloride member of the family) was stable up to $320^{\circ} \mathrm{C}$ and transformed to an amorphous phase at higher temperature. Iowaite experiences continuous contraction of the $d_{00 n^{-}}$-value of up to $0.5 \AA$ in the temperature range $25-200^{\circ} \mathrm{C}$, reaching a plateau at a temperature range of $200-320^{\circ} \mathrm{C}$. Assessing the reversibility of thermal transformation shows complete reconstruction of the crystal structure of the hydrotalcite and iowaite heated to $300{ }^{\circ} \mathrm{C}$. Solid-state nuclear magnetic resonance analysis shows that some $\mathrm{Al}$ changes coordination from 6- to 4-fold, synchronously with quintinite transformation to the amorphous phase. All phases transform to periclase and a spinel-type compound upon further heating. Thermal analysis of samples annealed at $125^{\circ} \mathrm{C}$ shows that carbonate members do not have a tendency to form dehydrated phases, whereas for iowaite, a dehydrated phase having 0.9 apfu lesser water content as in the initial sample has been obtained. Thermal evolution of LDHs is found to depend on the nature of the interaction of interlayer species and water molecules to $\mathrm{H}$ atoms of the metal-hydroxide layer.
\end{abstract}

Keywords: high-temperature crystal chemistry; high-temperature behavior; layered double hydroxides; LDH; hydrotalcite supergroup; powder X-ray diffraction; thermogravimetric analysis; thermal evolution; thermal degradation; thermal decomposition; quintinite; stichtite; iowaite 


\section{Introduction}

Hydrotalcite-supergroup minerals are natural representatives of the layered double hydroxide (LDH) family, and considered analogues of the much more diverse, industrially applied, synthetic LDH materials. Critically, natural LDHs form relatively large, in some cases well-shaped crystals (Figure 1), from which single-crystal platelet may be extracted, when compared to the generally fine-grained, polycrystalline, low-order, synthetic LDH materials. Crystal structures of both natural and synthetic LDHs are built of positively charged edge-sharing octahedral (brucite- or gibbsite-type) layers, alternating with interlayer spaces occupied by anions and water molecules [1,2].
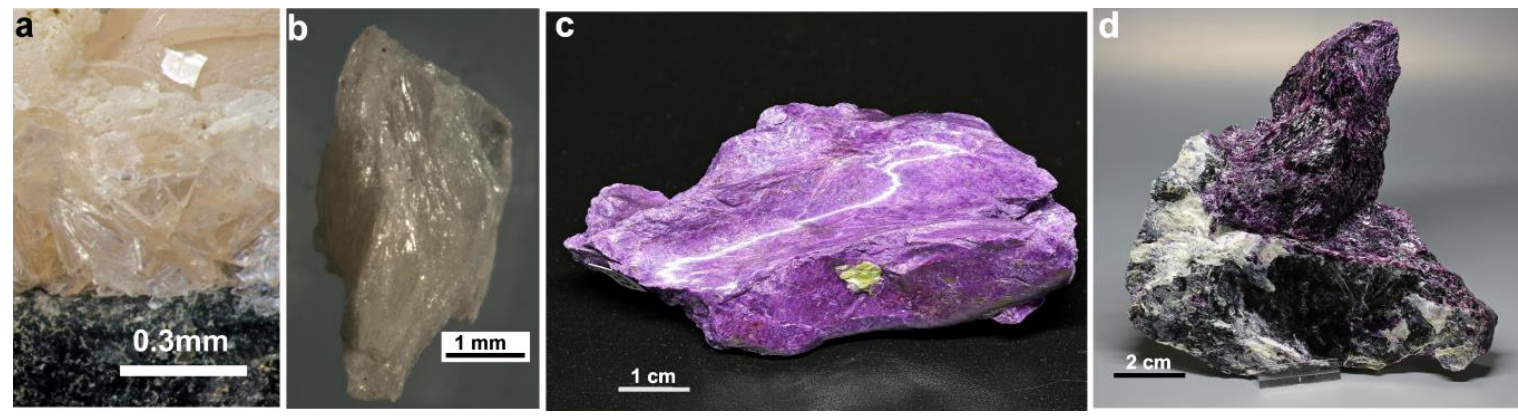

Figure 1. Photographs of minerals studied in this work: (a) quintinite, (b) hydrotalcite, (c) stichtite and (d) iowaite; $\mathrm{c}$ and $\mathrm{d}$-collection and photo: V.V. Levitskiy.

In this paper, we provide new data only for LDHs with brucite-type layers (i.e., those composed of di- and trivalent cations), with a generalized chemical formula expressed as $\left[\mathrm{M}^{2+}{ }_{1-x} \mathrm{M}^{3+}{ }_{x}(\mathrm{OH})_{2}\right]^{\mathrm{x}+}\left[A^{n-}\right]_{x / n} \cdot m \mathrm{H}_{2} \mathrm{O}$, where $M^{2+}: M^{3+}=$ divalent/trivalent metal cation ratio and $A=$ interlayer anion; where $x$ is generally in the range $0.2-0.33$. Currently, the hydrotalcite supergroup contains more than 40 representatives, divided into 8 groups by the $M^{2+}: M^{3+}$ ratio and the nature of interlayer anion [3]. Here, we provide new data for members of the hydrotalcite and quintinite groups (subdivisions of the hydrotalcite supergroup), among the most commonly formed in nature.

The high-temperature behavior of LDHs is actively studied because of their commercial application as catalysts or catalyst supports [4], flame retardant materials [5,6] or for $\mathrm{CO}_{2}$ capture during regeneration after heat-treating [7]. Importantly, industrially relevant highly basic mixed-metal oxides (MMOs) are obtained by thermal treatment (calcination) of LDHs [8], and these MMOs have a so-called "memory effect", transforming back to the parent LDH structure upon rehydration in an aqueous solution of the original anion, typically carbonate. The memory effect also underpins the potential application of calcined LDHs for sorption of different anions, including toxic and hazardous species, where the initially prepared carbonate LDH is difficult to anion exchange and thermolysis is required to generate the sorbent [9-13]. Though critical in applications of LDHs and regeneration of MMOs, it has proven difficult to obtain detailed mechanistic insight into thermal transformation of synthetic LDHs owing to the small crystal size (typically $<500 \mathrm{~nm}$ ) and high defect content.

The thermal behavior of the $\mathrm{Mg}-\mathrm{Al}-\mathrm{CO}_{3} \mathrm{LDH}$ series with different $\mathrm{Mg}$ : $\mathrm{Al}$ ratios has been long studied and, in general, is considered to be a reference system for $\mathrm{LDH}$ materials. Synthetic $\mathrm{Mg}-\mathrm{Al}-\mathrm{CO}_{3}$ samples have been studied by mass spectrometry, thermal analysis and powder X-ray diffraction, inter alia. The results from such studies agree in their identification of the following evolution steps: dehydration $\rightarrow$ dehydroxylation $\rightarrow$ decarbonation, with transformation to a high-temperature "collapsed" phase at about $400{ }^{\circ} \mathrm{C}$, followed by amorphization and decomposition to periclase and spinel-type material at higher temperature [14-17].

It is noteworthy that the crystal structures of the high-temperature "collapsed" modification of carbonate LDHs has been the subject of numerous research studies, both in terms of atomic arrangement and possible interpolytype transitions [18-25]. Regarding the atomic arrangement, 
the main widespread idea is that in the high-temperature "collapsed" modification, the carbonate group is grafted to the metal-hydroxide layer [26-29].

Despite the fact that the thermal behavior of synthetic LDHs is of wide interest and the subject of ongoing studies, the thermal behavior of natural (well-crystallized, commonly coarse crystalline and stable in geological time compounds) has scarcely been characterized. Thus, it is still not clear whether natural samples behave on heating in a way that is identical to their synthetic counterparts, despite their compositional similarity, and at the same time display chemistry owing to different impurities observed in natural LDHs. The high degree of structural perfection of natural LDHs provides a unique opportunity to study LDH decomposition, owing to no comparably highly ordered synthetic $\mathrm{LDH}$ ever having been prepared. In particular, how the difference in the bonding between $\left(\mathrm{CO}_{3}\right)^{2-}$ and $\mathrm{Cl}^{-}$-dominant hydrotalcite-supergroup minerals affects their thermal evolution is a question we seek to address. Furthermore, the role of interlayer water and its impact on dehydration of LDHs with different anions is also not completely understood [30].

The aim of the present paper is to provide systematic data for thermal decomposition of samples of four minerals: hydrotalcite, quintinite, stichtite, and iowaite, studied under the same conditions. These data will shed light on the influence of cation, anion and $\mathrm{M}^{2+}: \mathrm{M}^{3+}$ ratio on the thermal behavior of LDH minerals and synthetic materials.

\section{Materials and Methods}

\subsection{Materials}

During the present study, we investigated the high-temperature behavior of four hydrotalcite-supergroup minerals: quinitnite, hydrotalcite, $\mathrm{Fe}^{3+}$-rich stichtite and $\mathrm{Cr}^{3+}$-rich iowaite. These samples, including their chemical compositions and crystal structures including polytype identification, have been characterized previously (Table 1). All these minerals are representative for three structural groups of LDHs: carbonate with $\mathrm{M}^{2+}: \mathrm{M}^{3+}=2: 1$ (quintinite); carbonate with $M^{2+}: M^{3+}=3: 1$ (hydrotalcite and stichtite) and chloride with $M^{2+}: M^{3+}=3: 1$ (iowaite). The specimens of quintinite and hydrotalcite represent coarse lamellar aggregates while stichtite and iowaite occur as fine-scale masses (Figure 1). Monomineral samples were extracted from the specimens using tweezers and binocular microscope. The extracted samples were further ground with a mortar and pestle (one after another) to yield a powder for analysis.

Table 1. Minerals and their annealed forms studied in this work.

\begin{tabular}{|c|c|c|c|c|}
\hline Mineral & Locality & Chemical Formula & Polytype & Reference \\
\hline $\begin{array}{l}\text { Quintinite and } \\
\text { quint } 125^{*}\end{array}$ & $\begin{array}{c}\text { Kovdor, Kola } \\
\text { peninsula, Russia }\end{array}$ & {$\left[\mathrm{Mg}_{4.1} \mathrm{Al}_{1.9}(\mathrm{OH})_{12}\right]\left[\left(\mathrm{CO}_{3}\right)_{0.95}\left(\mathrm{H}_{2} \mathrm{O}\right)_{3}\right]$} & $1 M$ & [31] \\
\hline $\begin{array}{l}\text { Hydrotalcite and } \\
\text { htc125* }\end{array}$ & $\begin{array}{c}\text { Snarum, Modum, } \\
\text { Norway }\end{array}$ & {$\left[\mathrm{Mg}_{6} \mathrm{Al}_{2}(\mathrm{OH})_{16}\right]\left[\left(\mathrm{CO}_{3}\right)\left(\mathrm{H}_{2} \mathrm{O}\right)_{4}\right]$} & \multirow{3}{*}{$\begin{array}{c}\text { mixture of } 3 R \\
\text { (dominant) and } \\
2 H \\
\text { (subordinate) }\end{array}$} & [32] \\
\hline Stichtite & \multirow{2}{*}{$\begin{array}{l}\text { Terektinsky range, } \\
\text { Altai, Russia }\end{array}$} & {$\left[\mathrm{Mg}_{6}\left(\mathrm{Cr}, \mathrm{Fe}^{3+}\right)_{2}(\mathrm{OH})_{16}\right]\left[\left(\mathrm{CO}_{3}\right)\left(\mathrm{H}_{2} \mathrm{O}\right)_{4}\right]$} & & [33] \\
\hline Iowaite and iow125* & & {$\left[\mathrm{Mg}_{6}\left(\mathrm{Fe}^{3+}, \mathrm{Cr}\right)_{2}(\mathrm{OH})_{16}\right]\left[\mathrm{Cl}_{2}\left(\mathrm{H}_{2} \mathrm{O}\right)_{4}\right]$} & & [33] \\
\hline
\end{tabular}

* the samples of quintinite, hydrotalcite and iowaite annealed in oven at $125^{\circ} \mathrm{C}$ for $2 \mathrm{~h}$ (see text) are denoted as quint125, htc125, and iow 125 , respectively. The samples of quinitnite, hydrotalcite, stichtite, and iowaite have been characterized previously [31-33].

To study the reversibility of the dehydration behavior, the samples of quintinite, hydrotalcite and iowaite were annealed in an oven at $125^{\circ} \mathrm{C}$ for $2 \mathrm{~h}\left(30\right.$ min heating to $125^{\circ} \mathrm{C}, 1$-hour annealing at $125^{\circ} \mathrm{C}$ and $30 \mathrm{~min}$ cooling), samples are further denoted as quint 125 , htc125, and iow 125 , respectively. After the annealing, these samples were left under atmospheric humidity conditions for a month and then studied by thermal analysis. 


\subsection{Methods}

\subsubsection{High-Temperature Powder X-ray Diffraction}

In situ high-temperature powder X-ray diffraction (HTXRD) experiments were undertaken for quintinite, hydrotalcite, stichtite, and iowaite in air using a Rigaku Ultima IV powder X-ray diffractometer $\left(\mathrm{Co}_{\mathrm{K} \alpha 1+2}\right.$ radiation, $40 \mathrm{kV} / 30 \mathrm{~mA}$, Bragg-Brentano geometry, PSD D-Tex Ultra) with a Rigaku HT 1500 high-temperature attachment, heating up to $1000{ }^{\circ} \mathrm{C}$. The samples were grinded to fine powder using agate mortar. A thin powder sample was deposited on a Pt sample holder $(20 \mathrm{~mm} \times 12 \mathrm{~mm} \times 2 \mathrm{~mm})$ from a heptane suspension. The temperature step and the average heating rate were $20^{\circ} \mathrm{C}$ and $2 / 3 \% \mathrm{~min}$, respectively, and the collecting time at each temperature step was about $20 \mathrm{~min}$. Two representative powder diffraction patterns at increasing temperature are given in Figure 2a,d.
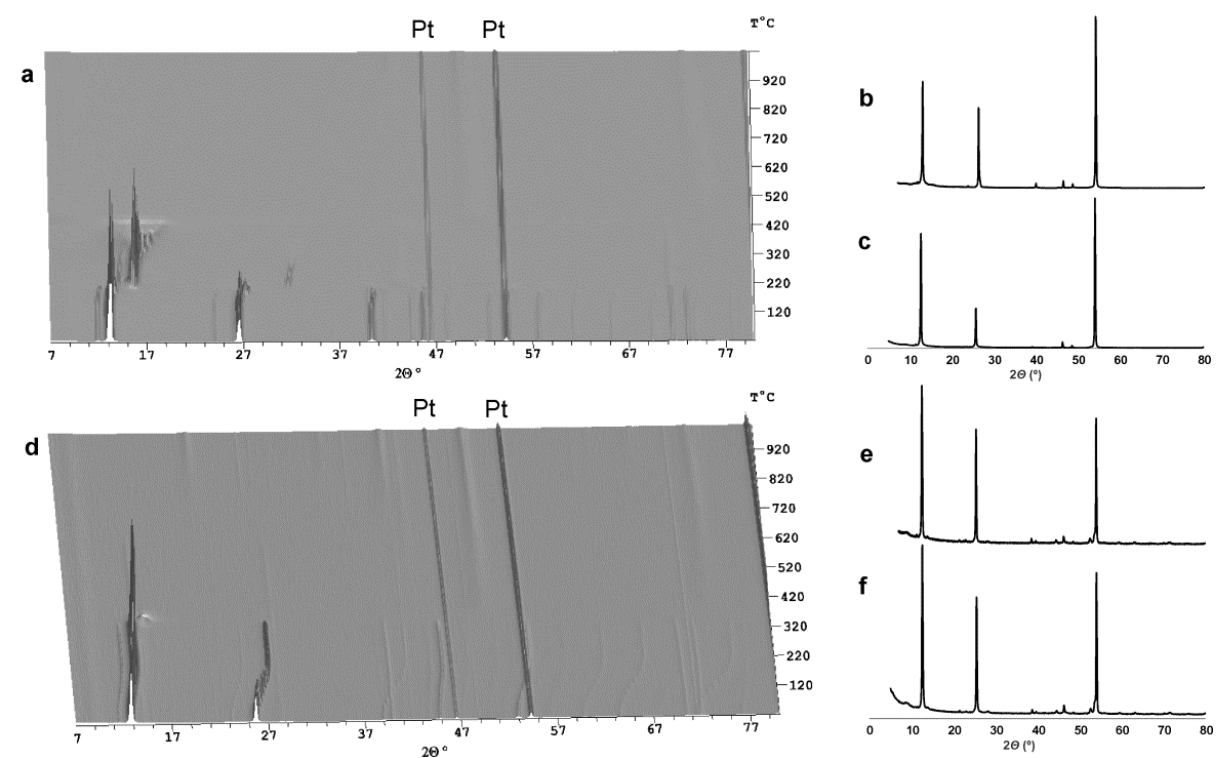

Figure 2. The powder $\mathrm{X}$-ray diffraction patterns recorded for hydrotalcite in the temperature range 25-1000 ${ }^{\circ} \mathrm{C}$ (a), before (b) and after annealing to $300{ }^{\circ} \mathrm{C}$ (c) and iowaite in the temperature range 25-1000 ${ }^{\circ} \mathrm{C}$ (d), before (e) and after annealing to $300{ }^{\circ} \mathrm{C}$ (f). Note: Pt indicates reflections from $\mathrm{Pt}$ sample holder.

The second heating cycle of untreated natural hydrotalcite was performed using the same instrument and conditions as detailed above, and using the following strategy: heating to $300{ }^{\circ} \mathrm{C}$ with a $20^{\circ} \mathrm{C}$ step, cooling to room temperature (RT) and re-recording the powder pattern (Figure $2 \mathrm{~b}, \mathrm{c}$ ). The second heating cycle of untreated natural iowaite was studied by HTXRD from RT to $300^{\circ} \mathrm{C}$ with a $20{ }^{\circ} \mathrm{C}$ step size, followed by cooling from $300{ }^{\circ} \mathrm{C}$ to RT with a $20^{\circ} \mathrm{C}$ step (Figure 2e,f).

\subsubsection{Thermal Analysis}

Differential scanning calorimetry (DSC) and thermogravimetric (TG) analysis were undertaken for all four minerals, ground to powder prior to analysis, using a DSC/TG Netzsch STA 449 F3 instrument in the temperature range $30-1000{ }^{\circ} \mathrm{C}$ at a ramp rate of $10^{\circ} \mathrm{C} \mathrm{min}-1$, heating the samples under $\mathrm{Ar}$ atmosphere with a gas flow of $20 \mathrm{~mL} / \mathrm{min}$. Another set of measurements was carried out for samples quint125, htc125, and iow125 that were annealed in an oven (see Section 2.1. Materials).

For thermal analysis interpretation we will need to distinguish the following types of water: (i) sorbed $=$ absorbed/adsorbed to external surfaces of the LDH crystals and thus released at relatively low temperature (but without distinct thermal effects, which makes it difficult to separate it from water of the next type); (ii) structurally required and tightly bonded interlayer water (i.e., $\left(\mathrm{H}_{2} \mathrm{O}\right)^{0}$ molecules) 
that is lost in a distinct dehydration step; (iii) hydroxyl $(\mathrm{OH})^{-}$groups that form strong hydrogen bond with $\mathrm{O}$ atoms from the metal-hydroxide layer (i.e., form $M(\mathrm{OH})_{6}, M$-cation) that are released at dehydroxylation step.

\subsubsection{Solid-State Nuclear Magnetic Resonance (NMR) at Increasing Temperature}

Non-spinning aluminum $\left(\mathrm{Al}^{27}\right)$ spectra, as a function of temperature, were recorded for quintinite using a Bruker Avance III HD spectrometer in the Department of Chemistry, Durham University. The operating frequency of NMR spectrometer was $104.27 \mathrm{MHz}$ for ${ }^{27} \mathrm{Al}$ (or $400.17 \mathrm{MHz}$ for ${ }^{1} \mathrm{H}$ ). A sequence of spectra was collected at 100, 150, 200, 250, 300 and $340^{\circ} \mathrm{C}$. Each spectrum took just over 3 min to record.

\section{Results}

\subsection{High-Temperature Powder X-ray Diffraction}

The analysis of the powder X-ray diffraction patterns with increasing temperature indicates that the three carbonate LDH minerals have more or less similar behavior, and this differs for the chloride containing iowaite. Here, we first compare and discuss the carbonate LDH minerals, followed by the chloride.

\subsubsection{Carbonate Members: Quintinite, Hydrotalcite, and Stichtite}

In the temperature range from 25 to $\sim 200{ }^{\circ} \mathrm{C}$ quintinite, hydrotalcite, and stichtite all experience contraction of the $d_{00 n}$-value (the distance between two adjacent metal-hydroxide layers) of $0.1-0.3 \AA$, i.e., from $7.6 \AA$ for quintinite and $7.8 \AA$ for hydrotalcite and stichtite [34] to $7.5 \AA$. Then, a sharp contraction of $d_{00 n}$-value occurs of $0.9 \AA$ (at $T=210{ }^{\circ} \mathrm{C}$ ) for quintinite; $1.0 \AA$ (at $T=190{ }^{\circ} \mathrm{C}$ ) for hydrotalcite and $1.1 \AA$ (at $T=170{ }^{\circ} \mathrm{C}$ ) for stichtite (Figure 3). These high-temperature (HT) "collapsed" modifications remain stable up to 420,400 and $380{ }^{\circ} \mathrm{C}$ for quintinite, hydrotalcite, and stichtite, respectively. It can be seen from Figure 2a that HT modifications are characterized by reduction in the intensity of reflections, especially for non-basal reflections that indicate decrease of crystallinity (i.e., decrease of ordering in atomic arrangement). It is of interest that the behavior of HT modifications in the temperature range $\sim 200-400{ }^{\circ} \mathrm{C}$ are different: the $d_{00 n}$-value continues to reduce for hydrotalcite and stichtite, whereas for quintinite, above $300{ }^{\circ} \mathrm{C}$, it increases (Figure 3a). This may indicate that in the case of quintinite (with $M^{2+}: M^{3+} \approx 2$ ), the HT modification has stabilized (at $T \sim 300{ }^{\circ} \mathrm{C}$ ) and the material then undergoes expansion of the basal values. However, in the crystal structures of hydrotalcite and stichtite (both with $M^{2+}: M^{3+} \approx 3$ ) it seems the rearrangement of interlayer atoms occurs until the breakdown of HT modifications, demonstrated by a strong and continuous contraction of their $d_{00 n}$-values. 

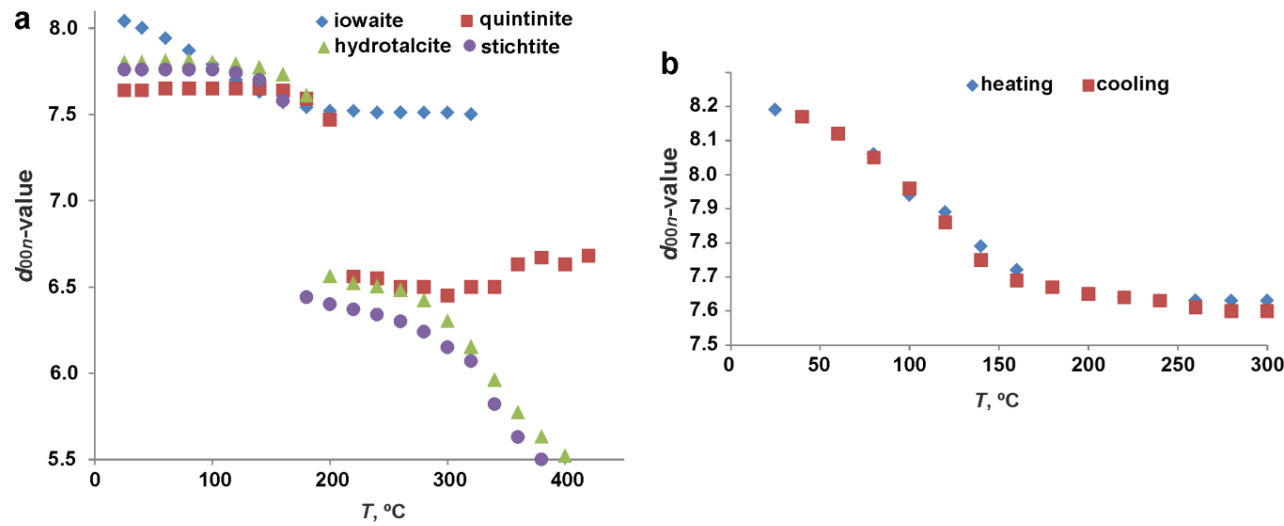

Figure 3. The evolution of $d_{00 n}$-value with increasing temperature for: (a) to $420{ }^{\circ} \mathrm{C}$ for quintinite, hydrotalcite, stichtite, iowaite and their corresponding HT modifications and (b) to $300{ }^{\circ} \mathrm{C}$, followed by cooling to RT for iowaite (reversibility check).

At temperature above $380-420{ }^{\circ} \mathrm{C}$ amorphization of hydrotalcite-supergroup members occurs. Reflections of periclase appear almost simultaneously with amorphization. Gradually, with increasing temperature, several regions with an increased background appear which transform to reflections of spinel-type compounds with increasing temperature (spinel, magnesioferrite, or magnesiochromite depending on starting composition).

In general, the overall decomposition reaction can be described in full as the following (using the example of quintinite):

$$
\begin{gathered}
\mathrm{Mg}_{4} \mathrm{Al}_{2}(\mathrm{OH})_{12} \mathrm{CO}_{3}\left(\mathrm{H}_{2} \mathrm{O}\right)_{3} \rightarrow 3 \mathrm{MgO}+\mathrm{MgAl}_{2} \mathrm{O}_{4}+9 \mathrm{H}_{2} \mathrm{O}+\mathrm{CO}_{2} \\
\text { quintinite periclase spinel water carbon dioxide }
\end{gathered}
$$

However, the decomposition process occurs by stages (Figure 4): (i) the studied LDH mineral transforms to an amorphous phase; (ii) reflections corresponding to periclase-type phase appear almost instantly after amorphization and then increase intensity, indicating in situ crystallization, the amorphous phase (reflected by broad humps at diffraction pattern) is still present; (iii) spinel-type phase crystallizes (space group $F d 3 m$ ) at increasing temperature in situ and, seemingly, over a longer time (and thus more energy) than in the case of periclase.
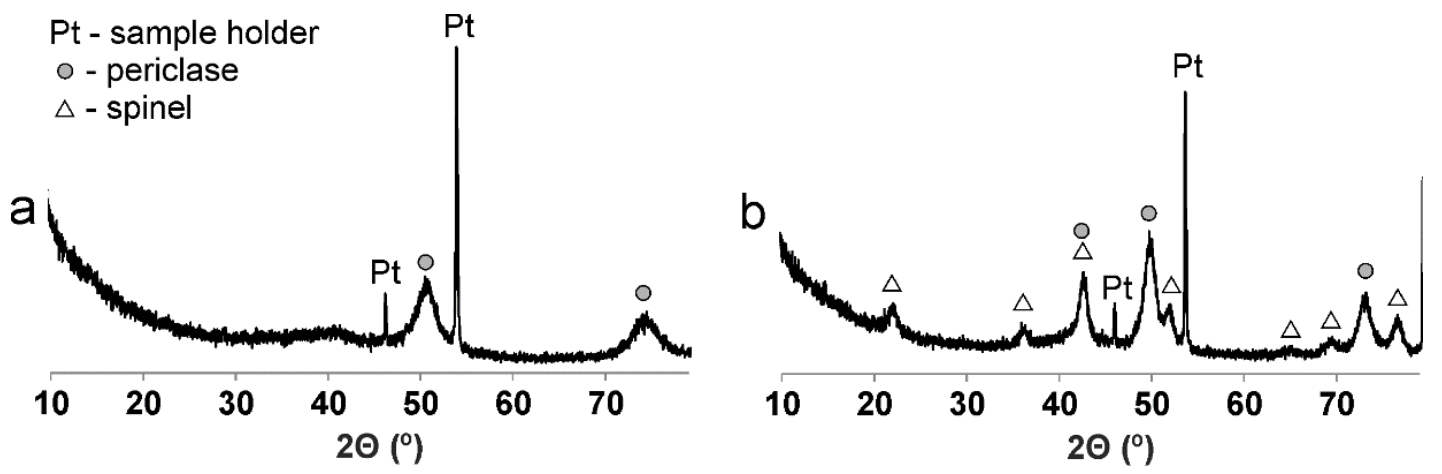

Figure 4. The powder patterns of quintinite decomposition products at (a) 500 and (b) $1000{ }^{\circ} \mathrm{C}$.

\subsubsection{Chlorine Member: Iowaite}

The behavior of iowaite (chloride member) with increasing temperature is strikingly different from that observed for the carbonate members, because it did not show a sudden contraction of the $d_{00 n}$-value and did not transform to yield a HT "collapsed" modification. Iowaite was stable up 
to $320^{\circ} \mathrm{C}$ and experienced continuous contraction of the $d_{00 n}$-value from $8.0[33,35]$ to $7.5 \AA$ in the temperature range $25-200^{\circ} \mathrm{C}$, before reaching a plateau in the temperature range $200-320^{\circ} \mathrm{C}$.

Amorphization of iowaite occurred above $320^{\circ} \mathrm{C}$ and the decomposition products appeared identical to that of the carbonate members: first, reflections corresponding to periclase appeared and, later, reflections from a spinel-type compound (magnesioferrite) were found.

\subsubsection{Reversibility Check}

Study of the powder X-ray diffraction patterns of hydrotalcite and iowaite heated to $300{ }^{\circ} \mathrm{C}$ and then cooled to RT indicated complete reversibility of structural changes in both cases (Figure $2 c, d$ ). The evolution of $d_{00 n}$-value with temperature obtained for iowaite heated to $300{ }^{\circ} \mathrm{C}$ and cooled step-by-step back to RT is shown in Figure 3b.

\subsection{Thermal Analysis}

According to thermal analysis data, the carbonate members shared similar decomposition features, whereas the chloride containing iowaite behaved differently, in agreement with observed differences evident in the powder X-ray diffraction analysis.

\subsubsection{Carbonate Members: Quintinite, Hydrotalcite, and Stichtite}

The carbonate members experienced two major events that are both endothermal in the range 25-600 ${ }^{\circ} \mathrm{C}$, followed by mass losses at $\mathrm{T}$ (mass loss): $234^{\circ} \mathrm{C}(14.34 \%)$ and $449^{\circ} \mathrm{C}(29.68 \%)$ for quintinite; $202{ }^{\circ} \mathrm{C}(14.55 \%)$ and $425{ }^{\circ} \mathrm{C}(34.04 \%)$ for hydrotalcite; $214{ }^{\circ} \mathrm{C}(14.36 \%)$ and $371{ }^{\circ} \mathrm{C}(30.01 \%)$ for stichtite (Figure $5 \mathrm{a}-\mathrm{d}$ ). The first mass loss corresponds to the loss of interlayer (molecular) water-dehydration step (Table 2). The second mass loss corresponds to a total loss of $\sim 42-46 \%$ (Table 2 ) implying that only metal oxides remained thereafter, with a complete absence of any volatile constituent. The region 600-1200 ${ }^{\circ} \mathrm{C}$ has not been studied in detail, within this present study, but the thermal effects that occur $\sim 1000^{\circ} \mathrm{C}$ probably indicate formation of spinel-type phase (in agreement with powder diffraction data). The detailed interpretation of these results, as well as discussion of the exothermic events, is given in Section 4.4.
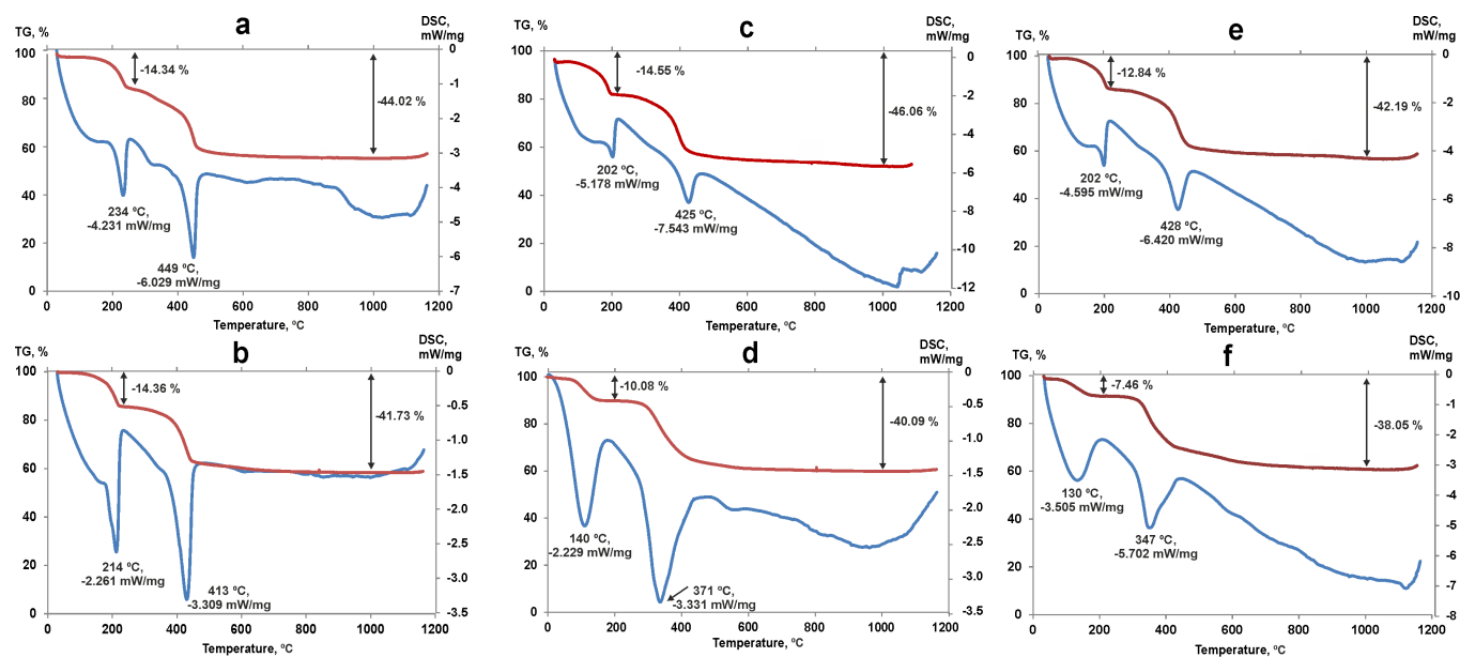

Figure 5. DSC and TG curves of quintinite (a), hydrotalcite (b), stichtite (c), iowaite (d), annealed hydrotalcite, sample htc125 (e) and annealed iowaite, sample iow125 (f). 
Table 2. Chemical composition of quintinite, hydrotalcite, stichtite, and iowaite obtained by electron-microprobe analyses of polished sections.

\begin{tabular}{|c|c|c|c|c|}
\hline Constituent, wt. $\%$ & Quintinite $^{1}$ & Hydrotalcite ${ }^{2}$ & Stichtite $^{3}$ & Iowaite $^{4}$ \\
\hline $\mathrm{MgO}$ & 33.82 & 40.04 & 37.99 & 38.06 \\
\hline $\mathrm{Al}_{2} \mathrm{O}_{3}$ & 19.58 & 15.9 & 2.14 & 2.01 \\
\hline $\mathrm{Fe}_{2} \mathrm{O}_{3}$ & n.d. & 1.08 & 8.94 & 10.45 \\
\hline $\mathrm{Cr}_{2} \mathrm{O}_{3}$ & n.d. & n.d. & 11.43 & 9.16 \\
\hline Eoxides & 53.40 & 57.02 & 60.05 & 59.68 \\
\hline $\mathrm{H}_{2} \mathrm{O}$ (as $\mathrm{OH}$ groups) & 22.05 & 23.77 & 22.45 & 22.51 \\
\hline $\mathrm{H}_{2} \mathrm{O}$ (molecular) & 11.03 & 11.87 & 11.22 & $10.08 *$ \\
\hline $\mathrm{CO}_{2}$ & 8.50 & 7.2 & 6.67 & n.d. \\
\hline $\mathrm{Cl}^{2}$ & n.d. & n.d. & 0.03 & 9.97 \\
\hline Evolatile & 41.58 & 42.84 & 40.37 & 42.56 \\
\hline Reference & 1 & 2 & \multicolumn{2}{|c|}{3} \\
\hline
\end{tabular}

\subsubsection{Chlorine Member: Iowaite}

Iowaite has two endothermal effects followed by mass losses: (i) at $T=140{ }^{\circ} \mathrm{C}$ with a mass loss of $10.08 \%$ and (ii) at $T=371{ }^{\circ} \mathrm{C}$ with a mass loss of $30.01 \%$. It is worth noting that the first mass loss is lesser than in any carbonate LDH studied here, pointing to the fact that $\mathrm{Cl}$-dominant LDHs contain lesser water molecules in comparison to carbonate members.

\subsubsection{Annealed Samples}

The thermal analysis of quint125, htc125, and iow 125 show that DSC and TG curves of quint125 and htc125 are similar to that of untreated samples of quintinite and hydrotalcite, while iow 125 has some differences when compared to untreated iowaite (Figure $5 \mathrm{e}, \mathrm{f}$ ).

For the annealed form of quintinite, quin125, the first mass thermal effect is found at $223{ }^{\circ} \mathrm{C}$ with corresponding mass loss of $13.47 \%$. The second thermal effect occurs at $443{ }^{\circ} \mathrm{C}$ with a mass loss of $28.73 \%$.

For hydrotalcite and its annealed form (htc125) the temperatures are identical $\left(202{ }^{\circ} \mathrm{C}\right)$ for the first effect and nearly identical $\left(425\right.$ and $428^{\circ} \mathrm{C}$ ) for the second effect (Figure 5e). The main difference between untreated and annealed sample refers to the first mass loss that is $14.34 \%$ for hydrotalcite and $12.84 \%$ for its annealed form (htc125). The values $13.47 \%$ and $12.84 \%$ are anyway slightly higher than expected from the chemical composition of quintinite and hydrotalcite if we assume that only dehydration takes place (Table 2).

For iowaite and its annealed form (iow125), the thermal events (Figure 5f) of the latter are shifted to lower temperatures, i.e., the first effect occurs at $130{ }^{\circ} \mathrm{C}$ for annealed iowaite (instead of $140{ }^{\circ} \mathrm{C}$ as in the untreated sample), the second effect is found at $347^{\circ} \mathrm{C}$ (instead of $371^{\circ} \mathrm{C}$ as in the untreated sample). For iowaite, the first mass loss is $10.08 \%$, which according to a calculation corresponds to $3.6 \mathrm{apfu}$ of $\left(\mathrm{H}_{2} \mathrm{O}\right)^{0}$ (interlayer water). In the annealed iowaite the first mass loss is $7.46 \%$, which corresponds to 2.7 apfu of $\left(\mathrm{H}_{2} \mathrm{O}\right)^{0}$ implying the loss of 0.9 apfu of $\left(\mathrm{H}_{2} \mathrm{O}\right)^{0}$ after annealing. It may be concluded that in the case of iowaite, the dehydrated modification has been obtained that differs in thermal behavior from the untreated material.

\subsection{Solid-State Nuclear Magnetic Resonance at Increasing Temperature}

According to solid-state nuclear magnetic resonance, the Al maintains 6-fold coordination until the temperature of $300^{\circ} \mathrm{C}$ when a portion of $\mathrm{Al}$ converts to 4-fold coordination [36]. The proportion of tetrahedrally coordinated $\mathrm{Al}$ increases at $340{ }^{\circ} \mathrm{C}$, but remains in a lower quantity relative to the 6-coordinate Al. The temperature at which changes in Al coordination state occurs (Figure 6), 
coincides (taking into account some difference in the heating rate) with quintinite transformation to an amorphous phase.

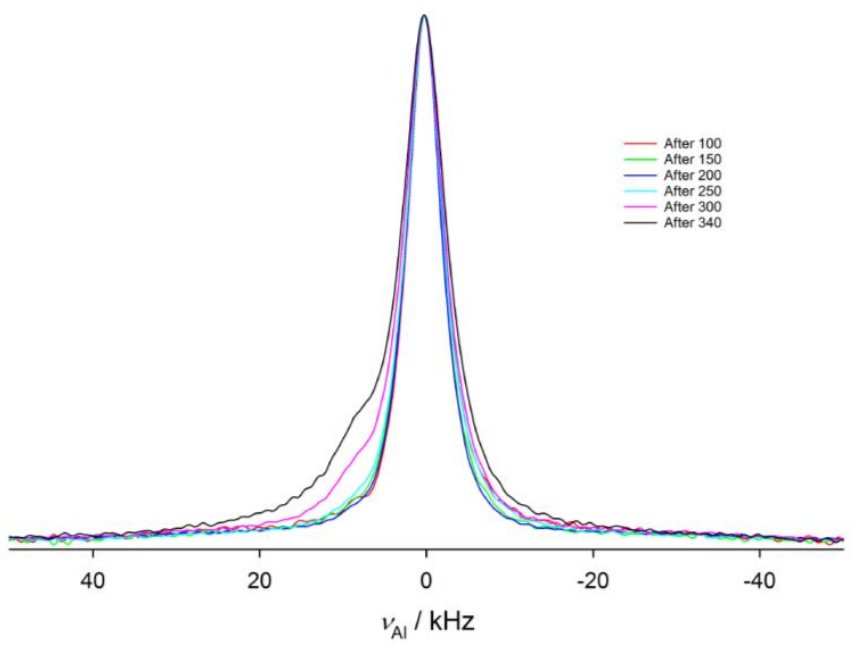

Figure 6. Non-spinning $\mathrm{Al}$ spectra from quintinite as a function of temperature.

\section{Discussion}

\subsection{The Influence of Cation Identity and Cation Ratio: $M^{2+}: M^{3+}=2: 1$ and 3:1 on Thermal Behavior}

In this work we have studied LDH carbonate species, which differ in their $M^{2+}: M^{3+}$ ratio, with 2:1 and 3:1, and different cation composition ( $\mathrm{Mg}-\mathrm{Al}$ and $\mathrm{Mg}-\mathrm{Cr}$ ) samples, with natural impurities. The temperature of $\mathrm{LDH}$ decomposition and transformation to an amorphous phase appeared to be similar for quintinite $\left(\mathrm{Mg}_{2} \mathrm{Al}\right)$, hydrotalcite $\left(\mathrm{Mg}_{3} \mathrm{Al}\right)$ and stichtite $\left(\mathrm{Mg}_{3} \mathrm{Cr}\right)$ and equal to 420,400 and $380{ }^{\circ} \mathrm{C}$, respectively. Therefore, there is indeed some tendency that lower $M^{2+}: M^{3+}$ ratios have higher thermal stability (for the example of quintinite and hydrotalcite) as suggested previously [15]; however this difference in decomposition temperature may be overlapped by the effect of cation composition of the octahedral layer (for the example of hydrotalcite and stichtite).

The trend in the evolution of the $d_{00 n}$-value is very similar for all carbonate LDH species investigated: for quintinite, hydrotalcite, and stichtite (Figure 3a), the main difference between them is that the $d_{00 n}$-value contracts by $0.1 \AA$ for quintinite, whereas for $3: 1 \mathrm{M}^{2+}: \mathrm{M}^{3+}$ ratio members (hydrotalcite and stichtite) the contraction is $0.3 \AA$. However, the high-temperature "collapsed" modifications of 2:1 and 3:1 $\mathrm{M}^{2+}: \mathrm{M}^{3+}$ ratio members behave differently. The high-temperature "collapsed" modification of quintinite starts with a $d_{00 n^{-}}$-value $=6.55 \AA$ (at $220^{\circ} \mathrm{C}$ ). This value contracts to $6.45 \AA$ (at $300^{\circ} \mathrm{C}$ ) and then undergoes expansion, reaching a value of $6.68 \AA$ (at $420^{\circ} \mathrm{C}$ ), just before decomposition. In contrast, the high-temperature "collapsed" modification of hydrotalcite and stichtite experience a continuous contraction of $d_{00 n}$-value from $6.56 \AA$ (at $200^{\circ} \mathrm{C}$ ) and $6.44 \AA$ (at $180{ }^{\circ} \mathrm{C}$ ) to $5.5 \AA$ just before decomposition. As noted above, it may indicate that the high-temperature "collapsed" modification of quintinite is stabilized in comparison to that of hydrotalcite and stichtite.

\subsection{The Influence of Interlayer Species on High-Temperature Behavior}

The main difference in the high-temperature evolution of the studied minerals can be attributed to the nature of the interlayer species, since the behavior of the Cl-dominant member (iowaite) appeared to be significantly different from the $\mathrm{CO}_{3}$-members (quintinite, hydrotalcite, and stichtite).

The HT behavior of the carbonate LDH minerals can be divided into the following stages:

i. From 25 to $170-210{ }^{\circ} \mathrm{C}$ dehydration (the loss of interlayer water) is accompanied by contraction of the $\mathrm{d}_{00 \mathrm{n}}$-value to $\sim 7.5 \AA$ with the main stage of dehydration appearing in the range from 
100 to $170-210{ }^{\circ} \mathrm{C}$, in accord with thermal analysis (Figure 5) and the $\mathrm{d}_{00 \mathrm{n}}$-value evolution (Figure 3).

ii. From 200 to $380-420^{\circ} \mathrm{C}$ dehydroxylation and decarbonization (the loss of $\mathrm{OH}$ groups associating with metal-hydroxide layer and interlayer carbonate) starting with a sharp contraction of $\mathrm{d}_{00 \mathrm{n}}$-value to 6.3-6.5 $\AA$, i.e., formation of a high-temperature "collapsed" modification. The structural changes are reversible at least up to $300{ }^{\circ} \mathrm{C}$. The partial change of $\mathrm{Al}$ coordination is recorded from $300^{\circ} \mathrm{C}$, indicating that some decomposition or irreversible transformation of the $\mathrm{LDH}$ has started. The amount of tetrahedrally coordinated $\mathrm{Al}$ increases with temperature, but remains minor relative to octahedrally coordinated Al.

iii. $\quad>\sim 400^{\circ} \mathrm{C}$ amorphization of quintinite, hydrotalcite, and stichtite. The reflections of periclase-type phase appear almost simultaneously with amorphization, whereas reflections of spinel-type phase appear at higher temperature.

The HT behavior of iowaite can be divided to the following stages:

i. $\quad 25-200{ }^{\circ} \mathrm{C}$ dehydration (the loss of interlayer water) accompanied by the contraction of the $\mathrm{d}_{00 \mathrm{n}}$-value from 8.0 to $7.5 \AA$.

ii. $\quad 200-320{ }^{\circ} \mathrm{C}$ thermal behavior of high-temperature dehydrated modification without changes in $\mathrm{d}_{00 \mathrm{n}}$-value which remains at 7.5 $\AA$. The dehydroxylation and dechlorination (the loss of $\mathrm{OH}$ groups associating with metal-hydroxide layer and interlayer $\mathrm{Cl}$ ) precedes the mineral decomposition. The structural changes related to dehydration are reversible, at least up to $300^{\circ} \mathrm{C}$.

iii. $\quad>\sim 320^{\circ} \mathrm{C}$ amorphization of iowaite. The reflections of periclase-type phase appear almost simultaneously with amorphization, whereas reflections of spinel-type phase appear at higher temperature.

From the above we can conclude that for natural LDHs: (i) the carbonate members have higher thermal stability than the $\mathrm{Cl}$-member and, (ii) for carbonate samples the loss of interlayer water leads to abrupt structural changes to a high-temperature "collapsed" modification, which is not characteristic for $\mathrm{Cl}$-members. For better understanding of the reason carbonate $\mathrm{LDH}$ members transform to high-temperature "collapsed" modifications [26-29], whereas chloride members do not, it is necessary to consider aspects of the crystal structure. Recently natural LDH members with carbonate: quintinite [31], hydrotalcite [32] and with chloride: chlormagaluminite [37] and dritsite [38] have been subjected to single-crystal X-ray diffraction study that allowed determination of fine structural detail (a summary is given in Figure 7). For easier interpretation of the crystal structure, it is convenient to consider the 3D atom arrangement as consisting of trigonal prisms, comprising the $\mathrm{H}$ atoms of an upper and lower metal-hydroxide layer (in accord with the approach of Bookin and Drits [39]). 

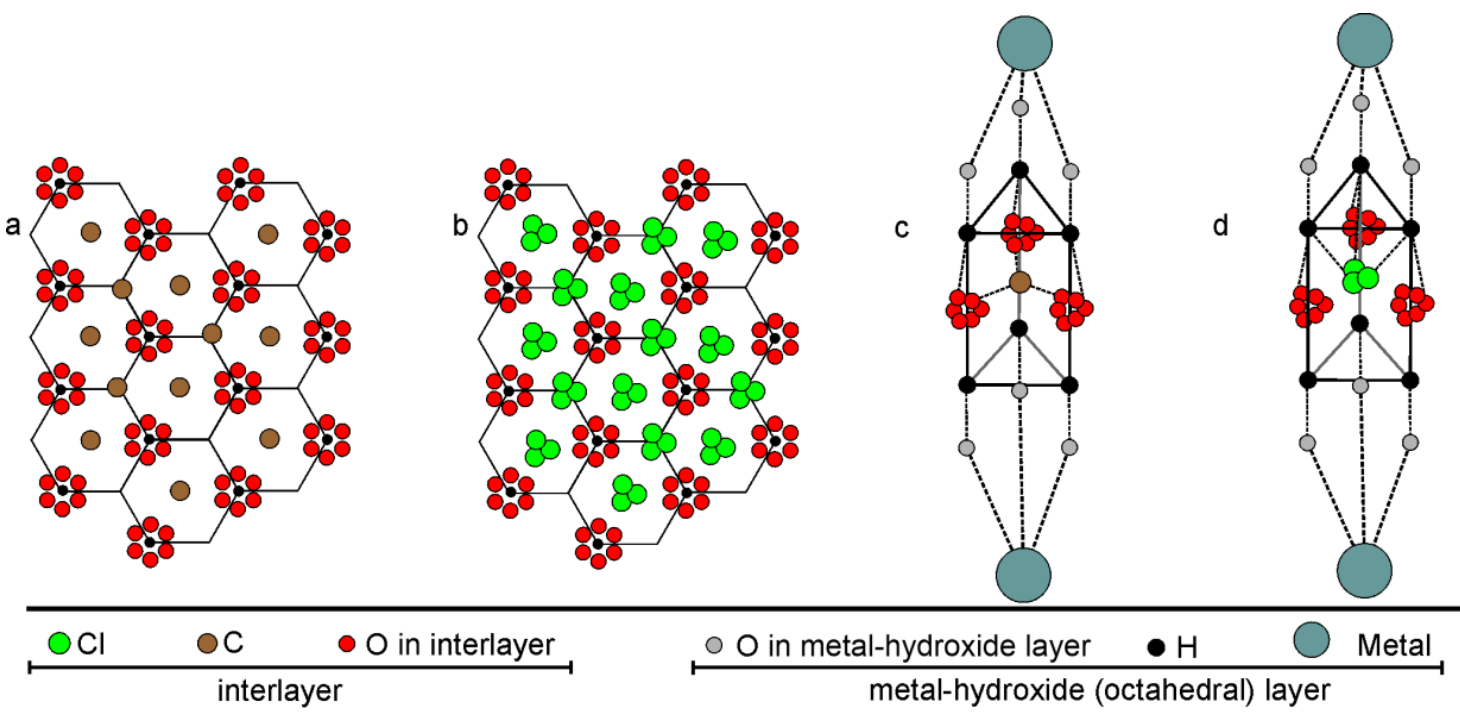

Figure 7. In-plane distribution of water molecules and interlayer species for: (a) carbonate and (b) chloride members, in accord with an earlier study [31,32,37,38], and the connection of water molecules and interlayer species along the stacking axis for (c) carbonate and (d) chloride members.

In the crystal structures of the carbonate members, the $\mathrm{C}$ atom is located in the center of the trigonal prism, whereas its $\mathrm{O}$ atoms are arrange around the prism edge, together with water molecules (Figure $7 \mathrm{a}, \mathrm{c}$ ). It is important to note that it is not possible to distinguish between the $\mathrm{O}$ atoms of $\mathrm{CO}_{3}$ groups and the $\mathrm{O}$ atoms of $\mathrm{H}_{2} \mathrm{O}$ molecules since they are disordered and appear in the structure refinement as continuous tors of electron density. In terms of bond arrangement, the $\mathrm{CO}_{3}$ group forms bonds laterally within the $x y$ plane, while $\mathrm{O}$ atoms of $\mathrm{H}_{2} \mathrm{O}$ are connected by bonds aligned almost parallel to the $z$ axes (Figure 7c).

In the crystal structures of the chloride members, the $\mathrm{Cl}$ anions are disordered around the prism center, whereas $\mathrm{H}_{2} \mathrm{O}$ molecules are disordered around the prism edge (Figure $7 \mathrm{~b}, \mathrm{~d}$ ). There are no lateral bonds in the $x y$ plane for interlayer atoms, since both $\mathrm{Cl}$ anion and $\mathrm{H}_{2} \mathrm{O}$ are connected exclusively with the upper and lower $\mathrm{H}$ atoms of metal-hydroxide layers owing to their geometry. For all studied minerals, the interlayer atoms are characterized by low occupancies and statistic disorder (i.e., Figure 7 shows atomic sites which are occupied in accord with chemical formula: 1 carbonate group or 2 chlorine anions per 6 (quintinite) or 8 (hydrotalcite, stichtite, and iowaite) atoms and 1 water molecule per 2 cations (for all species)).

The bond-valence structures [40] of the interlayer species: $\left(\mathrm{CO}_{3}\right)^{2-}, \mathrm{Cl}^{-}$, and $\mathrm{H}_{2} \mathrm{O}$ are represented in Figure 8. Bond valence is calculated as the formal charge of the central atom divided by the number of bonds, i.e., for carbonate group $4^{+} / 3=1.33$ valence units (v.u.) between $\mathrm{C}$ and $\mathrm{O}$ atoms, the remaining value ( 2 v.u. typical for $\mathrm{O}$ atom minus 1.33 v.u.) is $0.67 \mathrm{v} . \mathrm{u}$. and it is divided for bonding with both the upper and lower layer of the $\mathrm{LDH}$ as $0.33 \mathrm{v} . \mathrm{u}$. (Figure 8). Regarding the octahedral layer, there is one type of $\mathrm{OH}$ group in quinitinite (since all $\mathrm{OH}$ groups are coordinated by $2 \mathrm{Mg}$ and $1 \mathrm{Al}$ as the $\mathrm{Mg}: \mathrm{Al}=2: 1$ ) where each $\mathrm{H}$ atoms bears $0.17 \mathrm{v} . \mathrm{u}$. (the value is achieved by the charge on the sheet divided by the number of bonds emanating from the sheet, i.e., as 2/12). In hydrotalcite, stichtite, and iowaite $\left(\mathrm{M}^{2+}: \mathrm{M}^{3+}=3: 1\right)$ there are two types of OH groups: i) coordinated by $2 \mathrm{M}^{2+}$ and $1 \mathrm{M}^{3+}$ bearing 0.17 v.u. and (ii) coordinated by $3 M^{2+}$ which do not bear extra valence units for bonding with interlayer (as in brucite). The bond valence of the carbonate group, chloride anion, and water molecule are $0.33,0.17$, and 0.17 v.u., respectively (Figure 8). Thus, for all studied minerals with both $\mathrm{M}^{2+}: \mathrm{M}^{3+}=2: 1$ and 3:1 the bond-valence matching principle is satisfied between $\mathrm{H}$ atoms of the octahedral layer ( 0.17 v.u.) and interlayer $\mathrm{Cl}^{-}$anions ( 0.17 v.u.). For carbonate group we can assume that the hydrogen bonding between $\mathrm{O}$ atoms of $\left(\mathrm{CO}_{3}\right)^{2-}$ and $\mathrm{H}$ atoms of $\mathrm{H}_{2} \mathrm{O}$ molecules occurs (i.e., hydrogen bonding within interlayer similar to nickelalumite [41]). The in-plane bonding between 
carbonate and water molecule is demonstrated by the presence of broad band $\sim 3200 \mathrm{~cm}^{-1}$ at the infrared spectra of carbonate LDHs, assigned to the $\mathrm{CO}_{3}{ }^{2-}-\mathrm{H}_{2} \mathrm{O}$ bridging mode [42].
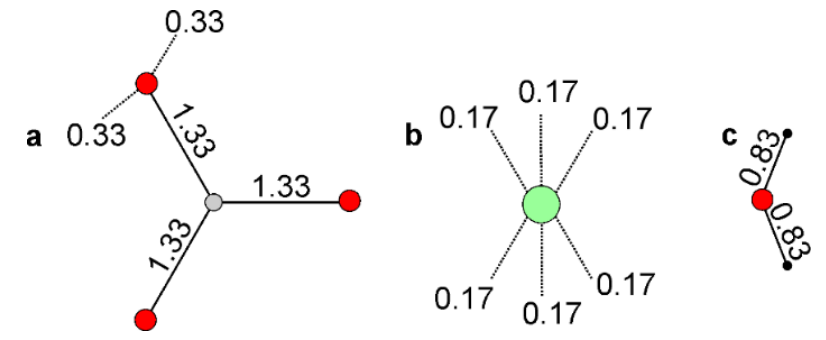

Figure 8. The bond-valence structure of the interlayer $(\mathbf{a})$ carbonate group $(\mathrm{C}=$ grey; $\mathrm{O}=$ red $),(\mathbf{b}) \mathrm{Cl}^{-}$ anions $(\mathrm{Cl}$ green) and (c) water molecules in LDHs $(\mathrm{O}=$ red; $\mathrm{H}=$ black), with the individual bond valences shown in valence units (v.u.).

Thus, the $\mathrm{H}_{2} \mathrm{O}$ molecule would be critical in maintaining bonding for carbonate LDHs. Then, the loss of $\mathrm{H}_{2} \mathrm{O}$ molecules (in the process of dehydration) will lead to the need for compensation for (i) under bonded $\mathrm{H}$ atoms of the metal-hydroxide layer (since their bonding depends on both metal-hydroxide layer and interlayer as two essential components) and, (ii) increasingly bonded $\mathrm{CO}_{3}$ groups, both potentially leading to complete reconstruction of the $\mathrm{CO}_{3}$ bonding with the formation of the metastable high-temperature "collapsed" modification. In the case of the $\mathrm{Cl}$-members, interlayer $\mathrm{Cl}^{-}$ anions and $\mathrm{H}_{2} \mathrm{O}$ molecules occupy distinct positions with each of them forming bonding to the metal-hydroxide layer (Figure 7).

For LDHs with interlayer $\mathrm{Cl}$ anions, the continuous loss of $\mathrm{H}_{2} \mathrm{O}$ molecules is compensated (in terms of bonding) by shortening of the distance between donor $(\mathrm{Cl})$ and acceptor $(\mathrm{H})$ atoms (Figure 3). It is worth noting that for iowaite, the $d_{00 n}$-value achieves plateau at $7.5 \AA$ in the temperature range of $200-320{ }^{\circ} \mathrm{C}$ (the obtained $d_{00 n}$-value is higher than the calculated by variable-cell first principles molecular dynamics for dehydrated $\mathrm{Mg}_{3} \mathrm{Al}-\mathrm{Cl}-\mathrm{LDH}$ which was estimated as $~ 7.2 \AA$ [43]). The temperature range $200-320^{\circ} \mathrm{C}$ probably corresponds to the thermal behavior of a dehydrated modification of iowaite. Thus, dehydration of $\mathrm{Cl}-\mathrm{LDH}$ does not trigger any principal rearrangement (and re-bonding) of the interlayer ion which is determined by anion geometry and its bonding scheme.

From the above discussion, it can be concluded that in the case of the carbonate LDH, dehydration destabilizes the carbonate group and leads to structural changes realized by formation of a high-temperature "collapsed" modification. Under a similar treatment, the dehydration of chloride members allows bond-strength compensation by shrinkage in the $d_{00 n}$-value, though without significant structural changes. If the argument presented above is correct, then it would be possible to check it by annealing the $\mathrm{CO}_{3}$ - and $\mathrm{Cl}$-members at temperature below $200{ }^{\circ} \mathrm{C}$ and then see whether they have a tendency to form dehydrated modifications (as has been done in this work).

The thermal analyses of annealed Cl-member: iowaite (iow125) showed $2.5 \mathrm{wt}$. \% lesser $\mathrm{H}_{2} \mathrm{O}$ content, which is equal to the loss of 0.9 apfu of $\mathrm{H}_{2} \mathrm{O}$ in comparison to the untreated sample. The thermal analyses of annealed carbonate members: quintinite (quint125) and hydrotalcite (htc125) resulted in almost identical water loss as in the untreated sample, with only a small difference in the amount of sorbed water.

From the above, it can be concluded that the thermal behavior and transformation of LDHs depends on the nature of the interactions between the interlayer species and water molecules with the $\mathrm{H}$ atoms of the metal-hydroxide layer. In the LDHs where lateral (in $x y$ plane) bonding between the anion and $\mathrm{H}_{2} \mathrm{O}$ molecules may occur (for example, $\mathrm{CO}_{3}$-members), the formation of the dehydrated modification will lead to principal structural changes, with atoms re-bonding or even material decomposition if such re-bonding is not possible. For the species where lateral bonding of interlayer ion and $\mathrm{H}_{2} \mathrm{O}$ molecule is disrupted or not possible (for example, Cl-members), the satisfaction of layer-interlayer 
bond strengths as a result of dehydration is simply achieved by contraction of the $d_{00 n}$-value without any considerable re-bonding.

\subsection{Comparison of Synthetic and Natural Samples}

\subsubsection{Quintinite and Hydrotalcite: $\mathrm{Mg}-\mathrm{Al}-\mathrm{CO}_{3}$ Series}

The thermal stability of natural samples of quintinite from Snarum (Norway) and synthetic analogues of quintinite and hydrotalcite have been studied in detail [44]. Data on the high-temperature behavior of quintinites from the Kovdor complex (Kola peninsula, Russia) are available from [45]. These data are compared to those obtained in this present work in Table 3. The comparison shows that the temperature of thermal effects is more or less similar for natural and synthetic quintinites, with the strongest deviation being for the 2 nd thermal event found for the synthetic sample $\left(420{ }^{\circ} \mathrm{C}\right)$ in comparison to the natural form $\left(447-463{ }^{\circ} \mathrm{C}\right)$. For hydrotalcite, the most notable difference is that between the 1 st thermal event in natural $\left(202{ }^{\circ} \mathrm{C}\right)$ and synthetic samples $\left(235^{\circ} \mathrm{C}\right)$, whereas the temperature of the second event is in better agreement (Table 3). However, the variation in the water content for different samples of both quintinite and hydrotalcite is within $2.5 \%$.

Table 3. Comparison of TG and DSC data for quintinite and hydrotalcite from different sources.

\begin{tabular}{cccccccc}
\hline Sample & \multicolumn{3}{c}{ Quintinite } & \multicolumn{2}{c}{ Hydrotalcite } \\
\hline Source & \multicolumn{3}{c}{ Natural } & & Synthetic & Natural & Synthetic \\
\hline Reference & This work & {$[44]$} & {$[45]$} & {$[45]$} & {$[44]$} & This work & {$[44]$} \\
\hline DSC $\left(\mathrm{T},{ }^{\circ} \mathrm{C}\right)$ 1st effect & 234 & 250 & 239 & 248 & 255 & 202 & 235 \\
\hline $\mathrm{TG}(\%)$ 1st effect & 14.3 & 15.5 & 15.3 & 13.1 & 15.6 & 14.5 & 17.0 \\
\hline $\mathrm{DSC}\left(\mathrm{T},{ }^{\circ} \mathrm{C}\right)$ 2nd effect & 449 & 455 & 447 & 463 & 420 & 425 & 415 \\
\hline $\mathrm{TG}(\%)$ 2nd effect & 29.7 & 27.3 & 25.8 & 25.9 & 27.3 & 31.5 & 27.3 \\
\hline
\end{tabular}

\subsubsection{Stichtite}

The first and only HT study of natural stichtite (from Nausahi ultramafites, Orissa, India) has been performed [46] by ex situ annealing of the mineral and identification of its decomposition products, which revealed that stichtite decomposes to a mixture of magnesiochromite (spinel-subgroup mineral) and periclase in samples subjected to annealing at temperature of $600-650{ }^{\circ} \mathrm{C}$ or $760-820^{\circ} \mathrm{C}$ for an hour and subsequently cooled. It was concluded that stichtite undergoes dehydration and decarbonation according to the following reaction at $600-650{ }^{\circ} \mathrm{C}$ :

$$
\mathrm{Mg}_{6} \mathrm{Cr}_{2} \mathrm{CO}_{3}(\mathrm{OH})_{16} \cdot 4 \mathrm{H}_{2} \mathrm{O} \rightarrow 5 \mathrm{MgO}+\mathrm{MgCr}_{2} \mathrm{O}_{4}+12 \mathrm{H}_{2} \mathrm{O}+\mathrm{CO}_{2}
$$

Stichtite Periclase Magnesiochromite

The data obtained in present study provides significantly more detail on the high-temperature behavior of stichtite, with aspects of the thermal evolution steps. However, regarding decomposition, our results agree with data for the samples from India [46].

Another study of stichtite thermal behavior has been undertaken for a synthetic analogue [47], and revealed the following mass losses: (a) $52{ }^{\circ} \mathrm{C}$ with the loss of $24.9 \%$; (b) at $294{ }^{\circ} \mathrm{C}$ with a mass loss of $22.5 \%$; (c) at $~ 550{ }^{\circ} \mathrm{C}$ with a mass loss of $2.5 \%$; (d) at $670{ }^{\circ} \mathrm{C}$ with a mass loss of $1.2 \%$. Of these data, the most remarkable is the first effect, with an extremely large mass loss (as also noted by the authors) that corresponds to 9 moles of water per 8 cations. From this we can assume that the synthetic material differed significantly from natural samples. It is hard to tell whether the difference was in chemistry with the product not precisely fitting to stichtite stoichiometry or the crystallite size played a big role in the product hydration, possible by large content of sorbed water, especially at edge sites. 


\subsubsection{Iowaite}

The thermal behavior of iowaite has been studied on two synthetic analogues: (i) a carbonate-bearing sample with chemical formula $\mathrm{Mg}_{6.27} \mathrm{Fe}_{1.73}(\mathrm{OH})_{16}(\mathrm{Cl})_{1.07}\left(\mathrm{CO}_{3}\right)_{0.33} \cdot 6.1 \mathrm{H}_{2} \mathrm{O}[48]$ and, (ii) iowaite-woodallite series (mixture) [49]. For both phases, again the authors reported the presence of excess interlayer water, i.e., $\sim 6 a p f u$ (instead of $4 a p f u$ as in the ideal formula). For the carbonate-bearing sample the thermal effects, with corresponding mass losses, have been identified as: step $1-35{ }^{\circ} \mathrm{C}(3.67 \%)$, step $2-79{ }^{\circ} \mathrm{C}(12.32 \%)$, step $3-254{ }^{\circ} \mathrm{C}$ (7.19\%), step $4-291{ }^{\circ} \mathrm{C}(11.8 \%)$, step $5-368{ }^{\circ} \mathrm{C}(2.2 \%)$, step $6-434^{\circ} \mathrm{C}$ (no loss) and step $7-574{ }^{\circ} \mathrm{C}(1.54 \%)$. Steps 1,2 are assigned to dehydration, steps 3,4-dehydroxylation, step 5, 6, and 7-dechlorination. For the iowaite-woodallite series, different samples, with variable $\mathrm{Fe}^{3+}: \mathrm{Cr}^{3+}$ (i.e., proportion iowaite/woodallite), have been studied, with results obtained for them in line with those of carbonate-bearing samples, and the conclusion was that the thermal stability of the synthetic iowaite-woodallite samples increased with iron content. The sequence of thermal evolution in these and the samples in our study appear to be similar: dehydration $\rightarrow$ dehydroxylation $\rightarrow$ dechlorination. However, the temperature of thermal effects and corresponding mass losses differ, which should probably be ascribed as due to the difference between synthetic and natural samples, as with stichtite.

\subsubsection{Water Content and Its Role}

From the comparison of present results for natural samples with the existing literature, it may be said that the general trends in thermal evolution of quintinite, hydrotalcite, stichtite, and iowaite agree with assumptions obtained for their synthetic analogues and follow dehydration $\rightarrow$ dehydroxylation $\rightarrow$ anion loss, based on strengths of bonding and the need to maintain charge compensation. It is worth noting that comparison to literature data on thermal analyses of natural samples (Table 3) shows that the variation of the first mass loss in within 13.1-15.5\% range (see details in Section 4.3.1), so the obtained here values of 13.47 and $12.84 \%$ are close to the lower previously detected values. However, even simple dehydration may significantly differ for natural and synthetic samples in the number of $\mathrm{H}_{2} \mathrm{O}$ molecules. Therefore, the true water content and its complete structural role are still not fully clear. In general, the trend is that synthetic samples have higher mass loss corresponding to dehydration in comparison to the natural. This can be explained by their small particle size, higher surface area, and higher sorption properties than those of the well-crystallized natural samples.

Despite the remaining lack of understanding of the position and bonding of interlayer water (structurally bonded), it seems to play a crucial role in thermal evolution of carbonate LDHs (as noted in Section 4.2) and other LDHs where hydrogen bonding between anions and water molecules within the interlayer is possible. In such cases, dehydration destabilizes the interlayer anion and leads to abrupt structural changes (i.e., collapse of interlayer for $1 \AA$ ), or may lead to sample decomposition, if the bond strengths match is not possible to achieve through interlayer contraction.

\subsection{Insight from Natural Quintinite into LDH Structure and Thermal Decomposition Events}

Through a careful series of experiments, [50] studied the thermal behavior of synthetic Mg:Al LDHs alongside the decomposition of synthetic aluminum trihydroxide (ATH) and magnesium hydroxide. Owing to its proximity to the dehydroxylation temperature of ATH, the authors ascribed the first endothermic event in $\mathrm{Mg}: \mathrm{Al}=2 \mathrm{LDHs}$ as being owing to dehydroxylation of the $\mathrm{Al}$ rich domains of the LDH structure. The higher temperature magnesium hydroxide decomposition event broadly aligned with the second endothermic event, and was ascribed to the decomposition of the, necessarily for $\mathrm{Mg}: \mathrm{Al}=2 \mathrm{LDH}, \mathrm{Mg}$ rich domains. However, owing to the cation avoidance rule, the $\mathrm{Al}$ cations in the natural quintinite sample of $\mathrm{Mg}: \mathrm{Al}=2$, must all be in an identical, ordered coordination state with $2 \mathrm{Mg}$ atoms and no Al-O-Al moieties. The ordering of $\mathrm{M}^{2+}$ and $\mathrm{M}^{3+}$ cations has been demonstrated (apart from NMR) by single-crystal and powder X-ray diffraction study by appearance of superstructure reflection $[31,37,38]$ that result in the fact that unit cell parameter $a=\sqrt{3} a^{\prime}$, where $a^{\prime}$ 
is the distance between two cations within octahedral layer. This poses a challenge to the previous assertion that the two, separate, endothermic events indicate two different $\mathrm{Mg}$ or $\mathrm{Al}$ rich domains as, were the $\mathrm{Al}$ cations perfectly ordered, there should only be one type of $\mathrm{Mg}_{2} \mathrm{Al}(\mathrm{OH})_{6}$ environment and, thus, only one thermally driven dehydroxylation event, not two.

Very recent studies, using recent advances in high spinning angle solid-state NMR [51,52], have identified that for synthetic LDH samples, there may be a small percentage (3-6\% of sites) that are not perfectly ordered and, thus would account for the two domains, though one might reasonably expect there to be a third, major endothermic event corresponding to the 93-97\% ordered environments, and the relative proportion of the mass losses associated with these events (Table 3) do not suggest that they are minor phases, even allowing for the absent major phase (corresponding to the ordered $\mathrm{Mg}_{2} \mathrm{Al}(\mathrm{OH})_{6}$ dehydroxylation) overlapping with one of them. On the basis of the above analysis, it would seem reasonable to suggest that external, loosely bound water, is removed early on in the heating (up to $60^{\circ} \mathrm{C}$ ) and that the first endothermic event at $234^{\circ} \mathrm{C}$ corresponds to the loss of the structural water detailed above, and not the decomposition of the aluminum rich, i.e., $\mathrm{Al}_{2} \mathrm{Mg}(\mathrm{OH})_{6}$, domains. The second endotherm then corresponds to the dehydroxylation of the more basic, $\mathrm{Mg}_{2} \mathrm{Al}(\mathrm{OH})_{6}$ domains, mainly all equivalent, sites at ca $449{ }^{\circ} \mathrm{C}$.

Analysis of the quintinite shows a $14.3 \%$ mass loss at $234{ }^{\circ} \mathrm{C}$ and a $29.7 \%$ mass loss at $449{ }^{\circ} \mathrm{C}$, giving a combined mass loss of $44 \%$. Calculated total mass loss for quintinite, based on the calculated formula (based on data in Table 1), suggests for complete decomposition to $3 \mathrm{MgO}$ and spinel, $\mathrm{MgAl}_{2} \mathrm{O}_{4}$, as per the equation above, an expected mass loss of $43.9 \%$, in excellent agreement with the $44 \%$ recorded in Table 3. However, if, as above, we assume all the structural water is lost at the first endotherm, and the second endotherm is the carbonate and hydroxyl group removal, we find calculated mass loss of $12.05 \%$ (measured $14.3 \%$ ) and $31.85 \%$ (measured $29.7 \%$ ), respectively.

It seems reasonable to speculate that to account for this discrepancy some small fraction of the carbonate reacts with certain layer hydroxyl groups during the first thermal event, alongside removal of structural water, thereby increasing the first mass loss through removal of $\mathrm{CO}_{2}$, and/or further $\mathrm{H}_{2} \mathrm{O}_{\text {, }}$ as observed in the experiment, and decreasing the second mass loss, also as observed. This would also concur with the NMR data [51,52] showing a small \% of locally non-equivalent Al sites in the $\mathrm{LDH}$, as well as explaining why the collapsed interlayer spacing occurs at this temperature with co-grafting of carbonate (and loss of water). The formation of new bonds during this reaction also accounts for the exotherm that immediately follows the first endotherm, rather than the previously proposed recrystallization of $\mathrm{Al}$ oxide/oxyhydroxide phases as proposed earlier [50]. The just released thorough and detailed investigation into nano-spinel formation [46], who examined decomposition of LDHs formed from oxide nanopowders support this suggested pathway, showing loss of $\mathrm{CO}_{2}$ by TGA MS corresponding to the end of the first endotherm, and onset of the following exotherm.

Further support may be garnered through comparison of the DSC trace of the chloride member-iowaite with the carbonate members. No exotherm is apparent following the first endotherm, which may be expected as, unlike carbonate, it is not possible for bonds to form between chloride and the LDH layer metals, whereas were the exotherms owing to Al recrystallization, it should be independent of anion type. Rather than interact act with the layers, $\mathrm{Cl}$ remains in the unreacted dehydrated interlayer until it is removed during the dehydroxylation phase as gaseous, balancing the $\mathrm{H}$ removal in the system, which carbonate forms do through generating water and $\mathrm{CO}_{2}$. The shoulder in the second endotherm and (albeit minor) exotherm immediately following it in the Cl-members analyzed (Figure 5d,f). Less structural water is present in the chloride during dehydration according to our experiments. The water is held less strongly, owing to weaker interactions and thus the endotherm starts at a lower temperature in the chloride member. 


\section{Conclusions}

Here we have shown that the natural LDHs, with high crystalline order, can be used to probe the structural properties of polycrystalline synthetic LDHs, as used in industry processes. The following specific conclusions can be drawn from the study:

1. In the range from 25 to $170-210{ }^{\circ} \mathrm{C}$ quintinite, hydrotalcite, and stichtite (carbonate members of the LDH family) demonstrated contraction of the basal $d_{00 n}$-value of $0.1-0.3 \AA$, followed by a sharp contraction of $1.0-1.1 \AA$ at $T>170-210{ }^{\circ} \mathrm{C}$. The high-temperature modified states were stable up to $380-420^{\circ} \mathrm{C}$, before decomposing to an amorphous phase. The structural changes are reversible at least up to $300{ }^{\circ} \mathrm{C}$. The partial change of $\mathrm{Al}$ coordination is recorded from $300{ }^{\circ} \mathrm{C}$, indicating that some decomposition or irreversible transformation of the LDH has started. The amount of tetrahedrally coordinated Al increases with temperature, but remains minor relative to octahedrally coordinated $\mathrm{Al}$.

2. Iowaite (chlorine member of the family) was stable up to $320^{\circ} \mathrm{C}$ and transformed to an amorphous phase at higher temperature. Iowaite experiences continuous contraction of the $d_{00 n}$-value of up to $0.5 \AA$ in the temperature range $25-200{ }^{\circ} \mathrm{C}$, reaching a plateau at a temperature range of 200-320 ${ }^{\circ} \mathrm{C}$. The structural changes are reversible at least up to $300^{\circ} \mathrm{C}$.

3. Thermal analysis of samples annealed at $125^{\circ} \mathrm{C}$ shows that carbonate members do not have a tendency to form dehydrated phases, whereas for iowaite a dehydrated phase having 0.9 apfu lesser water content as in the initial sample has been obtained.

4. The thermal behavior and transformation of LDHs depends on the nature of the interactions between the interlayer species and water molecules to the $\mathrm{H}$ atoms of the metal-hydroxide layer. The scheme of hydrogen bonding for carbonate LDHs determined destabilization of carbonate ion since dehydration step that results in abrupt structural transformations to high-temperature "collapsed" phase. For $\mathrm{LDH}$ with interlayer $\mathrm{Cl}$, the continuous loss of $\mathrm{H}_{2} \mathrm{O}$ molecules is compensated (in terms of bonding) by shortening of the distance between donor $(\mathrm{Cl})$ and acceptor (H) atoms.

5. The structural water is lost at the first endotherm, and the second endotherm is the carbonate and hydroxyl group removal, the calculated mass loss of $12.05 \%$ (measured $14.3 \%$ ) and $31.85 \%$ (measured 29.7\%), respectively. It seems reasonable to speculate that to account for this discrepancy some small fraction of the carbonate reacts with certain layer hydroxyl groups during the first thermal event, alongside removal of structural water, thereby increasing the first mass loss through removal of $\mathrm{CO}_{2}$, and/or further $\mathrm{H}_{2} \mathrm{O}$, as observed in the experiment, and decreasing the second mass loss, as was also observed.

In future work we will use these natural LDHs to probe the reaction mechanisms of LDH decomposition and cation migration within the LDH structure.

Author Contributions: Conceptualization, E.S.Z. and H.C.G.; investigation, E.S.Z., H.C.G., M.G.K., D.C.A.; data curation, I.V.P., V.N.Y.; writing—original draft preparation, E.S.Z., H.C.G.; writing—review and editing, E.S.Z., H.C.G., M.G.K., D.C.A., I.V.P., V.N.Y.; visualization, E.S.Z. All authors have read and agreed to the published version of the manuscript.

Funding: The reported study was funded by Russian Fund for Basic Research and the Royal Society according to the research project № 19-55-10005.

Acknowledgments: The research has been carried out using facilities of XRD Research Center of Saint Petersburg State University and the Solid-State NMR service at the Department of Chemistry, Durham University. We thank the reviewers for their comments and the editor for the manuscript handling.

Conflicts of Interest: The authors declare no conflict of interest.

\section{References}

1. Serna, C.J.; Rendon, J.L.; Iglesias, J.E. Crystal-chemical study of layered $\left[\mathrm{Al}_{2} \mathrm{Li}(\mathrm{OH})_{6}\right]^{+} \cdot n \mathrm{H}_{2} \mathrm{O}$. Clays. Clay. Miner. 1982, 30, 180-184. [CrossRef] 
2. Cavani, F.; Trifiro, F.; Vaccari, A. Hydrotalcite type anionic clays: Preparation, properties and applications. Catal. Today. 1991, 11, 173-301. [CrossRef]

3. Mills, S.J.; Christy, A.G.; Génin, J.M.R.; Kameda, T.; Colombo, F. Nomenclature of the hydrotalcite supergroup: Natural layered double hydroxides. Miner. Mag. 2012, 76, 1289-1336. [CrossRef]

4. Fan, G.; Li, F.; Evans, D.G.; Duan, X. Catalytic applications of layered double hydroxides: Recent advances and perspectives. Chem. Soc. Rev. 2014, 43, 7040-7066. [CrossRef] [PubMed]

5. Matusinovic, Z.; Wilkie, C.A. Fire retardancy and morphology of layered double hydroxide nanocomposites: A review. J. Mater. Chem. 2012, 22, 18701-18704. [CrossRef]

6. Gao, Y.; Wu, J.; Wang, Q.; Wilkie, A.; Hare, D.O. Flame retardant polymer/layered double hydroxide nanocomposites. J. Mater. Chem. A 2014, 2, 10996-11016. [CrossRef]

7. Albuquerque, D.W.S.; Costa, E.S.; de Miranda, J.L.; Gonçalves, R.D.; de Moura, L.C. Evaluation of the Behavior of Hydrotalcite Like-Materials for $\mathrm{CO}_{2}$ Capture. Appl. Mech. Mater. 2016, 830, 3-10. [CrossRef]

8. Gawande, M.B.; Pandey, R.K.; Jayaram, R.V. Role of mixed metal oxides in catalysis science-versatile applications in organic synthesis. Catal. Sci. Technol. 2012, 2, 1113-1125. [CrossRef]

9. Lv, L.; He, J.; Wei, M.; Evans, D.G.; Duan, X. Uptake of chloride ion from aqueous solution by calcined layered double hydroxides: Equilibrium and kinetic studies. Water Res. 2006, 40, 735-743. [CrossRef]

10. Ni, Z.M.; Xia, S.J.; Wang, L.G.; Xing, F.F.; Pan, G.X. Treatment of methyl orange by calcined layered double hydroxides in aqueous solution: Adsorption property and kinetic studies. J. Colloid Interface Sci. 2007, 316, 284-291. [CrossRef]

11. El Gaini, L.; Lakraimi, M.; Sebbar, E.; Meghea, A.; Bakasse, M. Removal of indigo carmine dye from water to $\mathrm{Mg}-\mathrm{Al}-\mathrm{CO}_{3}$-calcined layered double hydroxides. J. Hazard. Mater. 2009, 161, 627-632. [CrossRef]

12. Chetia, M.; Goswamee, R.L.; Banerjee, S.; Chatterjee, S.; Singh, L.; Srivastava, R.B.; Sarma, H.P. Arsenic removal from water using calcined $\mathrm{Mg}-\mathrm{Al}$ layered double hydroxide. Clean Technol. Envir. 2012, 14, $21-27$. [CrossRef]

13. Cai, P.; Zheng, H.; Wang, C.; Ma, H.; Hu, J.; Pu, Y.; Liang, P. Competitive adsorption characteristics of fluoride and phosphate on calcined $\mathrm{Mg}-\mathrm{Al}-\mathrm{CO}_{3}$ layered double hydroxides. J. Hazard. 2012, 213, 100-108. [CrossRef] [PubMed]

14. Bera, P.; Rajamathi, M.; Hegde, M.S.; Kamath, P.V. Thermal behaviour of hydroxides, hydroxysalts and hydrotalcites. B. Mater. Sci. 2000, 23, 141-145. [CrossRef]

15. Kanezaki, E. Thermal behavior of the hydrotalcite-like layered structure of $\mathrm{Mg}$ and Al-layered double hydroxides with interlayer carbonate by means of in situ powder HTXRD and DTA/TG. Solid State Ion. 1998, 106, 279-284. [CrossRef]

16. Valente, J.S.; Rodriguez-Gattorno, G.; Valle-Orta, M.; Torres-Garcia, E. Thermal decomposition kinetics of MgAl layered double hydroxides. Mater. Chem. Phys. 2012, 133, 621-629. [CrossRef]

17. Yang, W.; Kim, Y.; Liu, P.K.; Sahimi, M.; Tsotsis, T.T. A study by in situ techniques of the thermal evolution of the structure of a Mg-Al- $\mathrm{CO}_{3}$ layered double hydroxide. Chem. Eng. Sci. 2002, 57, 2945-2953. [CrossRef]

18. Thomas, G.S.; Radha, A.V.; Kamath, P.V.; Kannan, S. Thermally Induced Polytype Transformations among the Layered Double Hydroxides (LDHs) of Mg and Zn with Al. Phys. Chem. 2006, 110, 12365-12371. [CrossRef]

19. Thomas, G.S.; Kamath, P.V.; Kannan, S. Variable Temperature PXRD Studies of $\mathrm{LiAl}_{2}(\mathrm{OH})_{6} X^{*} \mathrm{H}_{2} \mathrm{O}(\mathrm{X}=\mathrm{Cl}$, Br): Observation of Disorder $\rightarrow$ Order Transformation in the Interlayer. Phys. Chem. C. 2007, 111, 18980-18984. [CrossRef]

20. Budhysutanto, W.N.; van Agterveld, D.; Schomaker, E.; Talma, A.G.; Kramer, H.J.M. Stability and transformation kinetics of $3 R_{1}$ and $3 R_{2}$ polytypes of $\mathrm{Mg}-\mathrm{Al}$ layered double hydroxides. Appl. Clay Sci. 2010, 48, 208-213. [CrossRef]

21. Cherepanova, S.; Leont'eva, N.; Drozdov, V.; Doronin, V. Thermal evolution of Mg-Al and Ni-Al layered double hydroxides: The structure of the dehydrated phase. Acta Cryst. A. 2016, 72, 651-659. [CrossRef] [PubMed]

22. Ramesh, T.N.; Maiya, P.S.; Jayaramu, M.; Sreenivasa, S. Thermal evolution of polytypic modifications during thermal decomposition studies of magnesium aluminium based layered double hydroxide. Int. J. Sci. Res. 2012, 1, 65-67.

23. Leont'eva, N.N.; Cherepanova, S.V.; Drozdov, V.A. Thermal decomposition of layered double hydroxides Mg-Al, Ni-Al, Mg-Ga: Structural features of hydroxide, dehydrated, and oxide phases. J. Struct. Chem. 2014, 55, 1326-1341. [CrossRef] 
24. Costa, D.G.; Rocha, A.B.; Souza, W.F.; Chiaro, S.S.X.; Leitão, A.A. Ab initio study of reaction pathways related to initial steps of thermal decomposition of the layered double hydroxide compounds. J. Phys. Chem. C. 2012, 116, 13679-13687. [CrossRef]

25. Shimamura, A.; Kanezaki, E.; Jones, M.I.; Metson, J.B. Direct observation of grafting interlayer phosphate in $\mathrm{Mg} / \mathrm{Al}$ layered double hydroxides. J. Solid State Chem. 2012, 186, 116-123. [CrossRef]

26. Vaysse, C.; Guerlou-Demourgues, L.; Delmas, C. Thermal evolution of carbonate pillared layered hydroxides with $(\mathrm{Ni}, \mathrm{L})(\mathrm{L}=\mathrm{Fe}, \mathrm{Co})$ based slabs: Grafting or nongrafting of carbonate anions? Inorg. Chem. 2002, 41, 6905-6913. [CrossRef]

27. Zhang, S.T.; Dou, Y.; Zhou, J.; Pu, M.; Yan, H.; Wei, M.; Evans, D.G.; Duan, X. DFT-Based Simulation and Experimental Validation of the Topotactic Transformation of MgAl Layered Double Hydroxides. Chem. Phys. Chem. 2016, 17, 2754-2766. [CrossRef]

28. Meng, Q.; Yan, H. Theoretical study on the topotactic transformation and memory effect of M (II) M (III)-layered double hydroxides. Mol. Simulat. 2017, 43, 1338-1347. [CrossRef]

29. Lyu, P.; Ertl, M.; Heard, C.J.; Grajciar, L.; Radha, A.V.; Martin, T.; Breu, J.; Nachtigall, P. Structure Determination of the Oxygen Evolution Catalyst Mössbauerite. J. Phys. Chem. C. 2019, 123, 25157-25165. [CrossRef]

30. Sotiles, A.R.; Gomez, N.A.G.; Wypych, F. Thermogravimetric analysis of layered double hydroxides intercalated with sulfate and alkaline cations $\left[\mathrm{M}_{6}{ }^{2+} \mathrm{Al}_{3}(\mathrm{OH})_{18}\right]\left[\mathrm{A}^{+}\left(\mathrm{SO}_{4}\right)_{2}\right] \cdot 12 \mathrm{H}_{2} \mathrm{O}\left(\mathrm{M}^{2+}=\mathrm{Mn}, \mathrm{Mg}, \mathrm{Zn} ; \mathrm{A}^{+}=\right.$ Li, Na, K). J. Therm. Anal. Calorim. 2019, 140, 1-9. [CrossRef]

31. Zhitova, E.S.; Krivovichev, S.V.; Yakovenchuk, V.N.; Ivanyuk, G.Y.; Pakhomovsky, Y.A.; Mikhailova, J.A. Crystal chemistry of natural layered double hydroxides. 4. Crystal structures and evolution of structural complexity of quintinite polytypes from the Kovdor alkaline massif, Kola peninsula, Russia. Miner. Mag. 2018, 82, 329-346. [CrossRef]

32. Zhitova, E.S.; Krivovichev, S.V.; Pekov, I.V.; Greenwell, H.C. Crystal chemistry of natural layered double hydroxides. 5. Single-crystal structure refinement of hydrotalcite, $\left[\mathrm{Mg}_{6} \mathrm{Al}_{2}(\mathrm{OH})_{16}\right]\left(\mathrm{CO}_{3}\right)\left(\mathrm{H}_{2} \mathrm{O}\right)_{4}$. Miner. Mag. 2019, 83, 269-280. [CrossRef]

33. Zhitova, E.S.; Pekov, I.V.; Chukanov, N.V.; Yapaskurt, V.O.; Bocharov, V.N. Minerals of the stichtite-pyroaurite-iowaite-woodallite system from serpentinites of Terektinsky range, Altay Mountains, Russia. Russ. Geol. Geoph. 2020, 61, 36-46.

34. Zhitova, E.S.; Krivovichev, S.V.; Pekov, I.V.; Yakovenchuk, V.N.; Pakhomovsky, Y.A. Correlation between the d-value and the $\mathrm{M}^{2+}: \mathrm{M}^{3+}$ cation ratio in $\mathrm{Mg}-\mathrm{Al}-\mathrm{CO}_{3}$ layered double hydroxides. Appl. Clay Sci. 2016, 130, 2-11. [CrossRef]

35. Braithwaite, R.S.W.; Dunn, P.J.; Pritchard, R.G.; Paar, W.H. Iowaite, a re-investigation. Miner. Mag. 1994, 58, 79-85. [CrossRef]

36. Hudson, M.J.; Carlino, S.; Apperley, D.C. Thermal conversion of a layered (Mg/Al) double hydroxide to the oxide. J. Mater. Chem. 1995, 5, 323-329. [CrossRef]

37. Zhitova, E.S.; Krivovichev, S.V.; Pekov, I.V.; Yapaskurt, V.O. Crystal Chemistry of Chlormagaluminite, $\mathrm{Mg}_{4} \mathrm{Al}_{2}(\mathrm{OH})_{12} \mathrm{Cl}_{2}\left(\mathrm{H}_{2} \mathrm{O}\right)_{2}$, a Natural Layered Double Hydroxide. Minerals 2019, 9, 221. [CrossRef]

38. Zhitova, E.S.; Pekov, I.V.; Chaikovskiy, I.I.; Chirkova, E.P.; Yapaskurt, V.O.; Bychkova, Y.V.; Belakovskiy, D.I.; Chukanov, N.V.; Zubkova, N.V.; Krivovichev, S.V.; et al. Dritsite, $\mathrm{Li}_{2} \mathrm{Al}_{4}(\mathrm{OH})_{12} \mathrm{Cl}_{2} \cdot 3 \mathrm{H}_{2} \mathrm{O}$, a new gibbsite-based hydrotalcite supergroup mineral. Minerals 2019, 9, 492. [CrossRef]

39. Bookin, A.S.; Drits, V.A. Polytype diversity of the hydrotalcite-like minerals. I. Possible polytypes and their dffraction patterns. Clay Clay Min. 1993, 41, 551-557. [CrossRef]

40. Brown, I.D. The Chemical Bond in Inorganic Chemistry, 2nd ed.; Oxford University Press: Oxford, UK, 2016.

41. Uvarova, Y.A.; Sokolova, E.; Hawthorne, F.C.; Karpenko, V.V.; Agakhanov, A.A.; Pautov, L.A. The crystal chemistry of the "nickelalumite"-group minerals. Can. Miner. 2005, 43, 1511-1519. [CrossRef]

42. Madej, D.; Tyrała, K. In Situ Spinel Formation in a Smart Nano-Structured Matrix for No-Cement Refractory Castables. Materials 2020, 13, 1403. [CrossRef] [PubMed]

43. Trave, A.; Selloni, A.; Goursot, A.; Tichit, D.; Weber, J. First principles study of the structure and chemistry of Mg-based hydrotalcite-like anionic clays. J. Phys. Chem. B. 2002, 106, 12291-12296. [CrossRef]

44. Stanimirova, T.; Piperov, N.; Petrova, N.; Kirov, G. Thermal evolution of Mg-Al-CO 3 hydrotalcites. Clay Miner. 2004, 39, 177-191. [CrossRef] 
45. Panikorovskii, T.L.; Zhitova, E.S.; Krivovichev, S.V.; Zolotarev, A.A.; Britivn, S.N.; Yakovenchuk, V.N.; Krzhizhanovskaya, M.G. Thermal «memory effect» in quintinite polytypes-2H,-3R, and-1M. Zapiski RMO 2015, 144, 109-119.

46. Mondal, S.K.; Baidya, T.K. Stichtite $\left[\mathrm{Mg}_{6} \mathrm{Cr}_{2}(\mathrm{OH})_{6} \mathrm{CO}_{3} \cdot 4 \mathrm{H}_{2} \mathrm{O}\right]$ in Nausahi ultramafites, Orissa, India-its transformation at elevated temperatures. Miner. Mag. 1996, 58, 69-78.

47. Frost, R.L.; Bouzaid, J.M. Thermal decomposition of stichtite. J. Therm. Anal. Calorim. 2007, 89, $133-135$.

48. Frost, R.L.; Bouzaid, J.; Musumeci, A.W.; Kloprogge, J.T.; Martens, W.N. Thermal decomposition of the synthetic hydrotalcite iowaite. J. Therm. Anal. Calorim. 2006, 86, 437-441. [CrossRef]

49. Frost, R.L.; Bouzaid, J.M.; Martens, W.N. Thermal decomposition of the composite hydrotalcites of iowaite and woodallite. J. Therm. Anal. Calorim. 2007, 89, 511-519.

50. Gusmano, G.; Nunziante, P.; Traversa, E.; Chiozzini, G. The mechanism of $\mathrm{MgAl}_{2} \mathrm{O}_{4}$ spinel formation from the thermal decomposition of coprecipitated hydroxides. J. Eur. Ceram. Soc. 1991, 7, 31-39. [CrossRef]

51. Cadars, S.; Layrac, G.; Gérardin, C.; Deschamps, M.; Yates, J.R.; Tichit, D.; Massiot, D. Identification and quantification of defects in the cation ordering in $\mathrm{Mg} / \mathrm{Al}$ layered double hydroxides. Chem. Mater. 2011, 23, 2821-2831. [CrossRef]

52. Sideris, P.J.; Nielsen, U.G.; Gan, Z.; Grey, C.P. Mg/Al ordering in layered double hydroxides revealed by multinuclear NMR spectroscopy. Science 2008, 321, 113-117. [CrossRef]

Publisher's Note: MDPI stays neutral with regard to jurisdictional claims in published maps and institutional affiliations. 